\title{
Kurumsal ve Finansal Raporlamanın Geleceği Üzerine Değerlendirmeler
}

\section{Evaluations on the Future of Corporate and Financial Reporting}

\author{
Hakan Cavlak ${ }^{1}$ (]) \\ 'Arş. Gör. Dr., Ardahan Üniversitesi, İktisadi ve İdari Bilimler Fakültesi, İşletme Bölümü, Ardahan, Türkiye
}

ORCID: H.C. 0000-0002-5891-7722

\section{öz}

İşletmelerin paydaşları ile iletişiminde kullandıkları en önemli araç kurumsal raporlardır. Kurumsal raporlar, kurumsal raporlama sürecinin bir nihai çıktısıdır ve işletmenin geçmiş faaliyetlerine ilişkin sonuçlar ile geleceğine yönelik öngörülerini içermektedir. Kurumsal raporlar içerisinde ise finansal raporlar, en uzun geçmişe ve en yaygın kullanıma sahip olan rapor türüdür. Bu çalışmada, zaman içinde piyasaların, işletme yapplarının, paydaş taleplerinin ve teknolojinin değişim göstermesi neticesinde kurumsal ve finansal raporlamada yaşanan ve gelecekte yaşanabilecek muhtelif değişiklikler incelenmektedir. Bu değişiklikler ağırlıklı olarak, finansal bilgi yanında finansal olmayan bilgiye ilişkin artan ilgi, maddi olmayan varlıkların önem kazanması, sürdürülebilirlik ve dijitalleşme olgusu ile birlikte kendini göstermiştir. Bunların bir neticesi olarak da farklı kurumsal rapor türleri ortaya çıkmış ve finansal raporlarda kendi içinde çeşitli değişimler göstermek zorunda kalmıştır. Gelecekte de kurumsal ve finansal raporlamaya ilişkin değişimin ve gelişimin muhtelif çerçevelerde devam edeceği öngörülmektedir. Diğer taraftan her alanda büyük bir belirsizlik ve etki oluşturan Covid-19 pandemisinin de kurumsal ve finansal raporlar üzerinde daha fazla açıklama şeklinde kendini gösterdiği göze çarpmaktadır. Ayrıca pandeminin ekonomik olarak oluşturduğu etkiden dolayı bu dönemde işletme paydaşlarının kurumsal raporlar içerisinde ağırlıklı olarak finansal raporlara daha fazla önem verdiği gözlemlenmektedir.

Anahtar kelimeler: Kurumsal raporlama, finansal raporlama, kurumsal rapor, finansal rapor, COVID-19

\section{ABSTRACT}

The most important tool that businesses use in communicating with their stakeholders is corporate reports. Also, corporate reports are the final output of the corporate reporting process. It includes the results of the past operating activities of the business and its predictions for the future. Among corporate reports, financial reports have the longest history and the most common use. Various changes in corporate and financial reporting as a result of changes in markets, operating structures, stakeholder demands, and technology are the subject of this study. The future of corporate and financial reporting is another issue discussed in the study. Increased interest in non-financial information, the increasing importance of intangible assets, sustainability, and digitalization are results of these changes. As a result of these, different types of corporate reports have emerged. Also, it was necessary for this study to document various changes in financial reports. Change and development regarding corporate and financial reporting will continue in various frameworks in the future. However, the Covid-19 pandemic, which has created great uncertainty and has impacted every field, has shown its effect on corporate and financial reports in the form of further disclosure. Also, due to the economic impact of the pandemic, it is observed that business stakeholders have attached more importance to financial reports compared to other corporate reports in this period.

Keywords: Corporate reporting, financial reporting, corporate report, financial report, COVID-19

Başvuru/Submitted: 20.09.2020 Kabul/Accepted: 02.11 .2020

Sorumlu yazar/Corresponding author: Hakan Cavlak / hcavlak85@gmail.com

Atıf/Citation: Cavlak, H. (2021). Kurumsal ve finansal raporlamanın geleceği üzerine değerlendirmeler. Muhasebe Enstitüsü Dergisi - Journal of Accounting Institute, 64, 39-58. https://doi.org/10.26650/MED.797559 


\section{Extended Abstract}

Businesses present the results of their operating activities and their future targets to their stakeholders through various tools. This communication between businesses and their stakeholders is mostly provided by corporate reports. Corporate reports, which are an output of the corporate reporting process, are presented in more than one form today (financial reportindependent audit report-, annual report, corporate governance compliance report, sustainability report, integrated report). Among these reports, financial reports are the type of corporate report with the longest history and the most common use. Financial reports have the longest history and the most common usage among these reports. Financial reports are the presentations of the financial statements created by the companies at the end of the financial reporting process. This presentation is generally provided by an independent audit report today. Financial statements, which are shown in detail in the independent audit report and are an output of the financial reporting process, are also shown in the annual reports of the companies in a summary manner. Also, companies almost do not use the term "financial report" when presenting these reports. As a result, the presentation of the financial statements that form the basis of the financial report is presented to the business stakeholders at the end of the financial reporting process under the name of "independent audit report" or "annual report". Apart from the report, financial statements and their data are presented under headings such as investor presentations and summary financial data on the websites of companies.

Changes in business structures, investor profile, stakeholder demands and technology, progress in environmental and social awareness, and similar factors have caused the information provided by financial reports to be insufficient to tell the whole story of the business. Therefore, non-financial information has been needed in the evaluation of businesses. Businesses try to meet this need by presenting different corporate reports (sustainability report and integrated report, etc.). In summary, the development of corporate reporting that started with financial reporting continues with different types of reports. Corporate reporting development, which improved with the annual report and corporate governance report, continued with sustainability report in the 2000 s and with integrated report in the 2010 s.

Although the scope of corporate reporting has undergone a great change in the last fifty years and different corporate reports have been created, the demand for financial reporting has not lost its effect. In other words, financial reports remain important, and the basis for decision-making. Factors such as the preparation of financial reports according to certain international standards, the use of a common language, the importance of financial information, and the fact that other types of corporate reports will always need the information produced by financial reports have been effective in this. However, it is acknowledged that financial reporting has changed in itself especially in response to stakeholder demands and technological progress.

Financial reports have been the cornerstone and driving element of corporate reporting for more than half a century. However, factors such as the economic structure that have moved from an industrial basis to a position driven by technology and information, and the change in stakeholder expectations have forced changes in both financial and corporate reports. It is predicted that issues such as the increasing demand for non-financial information, the increasing importance of intangible assets, the inclusion of big data, blockchain, cloud computing and artificial intelligence in reporting processes will guide the future of both corporate reports and financial reports. In this process, various responsibilities fall on both the reporting regulators, the companies that will carry out the reporting process, and the report users. Fulfilling these responsibilities effectively and in cooperation will ensure that corporate and financial reports are placed in the correct position of communication between the business and the stakeholders.

An issue that can be expressed in evaluations for the future of corporate and financial reporting is related to the environment of uncertainty created by Covid-19. The situation revealed by Covid-19 has led to an increase in the disclosures of businesses to their stakeholders through other communication tools, especially financial reports. In the Covid-19 period, business stakeholders, especially investors, have decreased their non-financial information requests from businesses compared to the pre-Covid-19 period and increased their demands for financial information. This indicates that financial reports have become more important in this extraordinary period compared to other corporate reports. On the other hand, businesses 
should pay more attention to matters such as business continuity, going concern, liquidity, cash management, assumptions, estimation processes, government grants, footnote disclosures, risk management and audit activities in the financial reporting process to be carried out during this period of uncertainty. It is also stated that the communication that businesses will establish with their stakeholders in this period will guide the future of corporate and especially financial reporting. 


\section{Giriş}

İşletmeler, faaliyetlerine ilişkin sonuçlar ile geleceğe ilişkin hedeflerini paydaşlarına muhtelif araçlar vasıtasıyla sunmaktadırlar. İşletmeler ile paydaşları arasındaki bu iletişim çoğunlukla kurumsal raporlar ile sağlanmaktadır. Kurumsal raporlama sürecinin bir çıktısı olan kurumsal raporlar, günümüzde birden fazla şekilde ( finansal raporlar-bağımsız denetim raporlarl-, ylllı faaliyet raporlarl, kurumsal yönetim ilkelerine uyum raporu, sürdürülebilirlik raporlarl, entegre raporlar) oluşturulabilmektedir. Bunların içinde ise finansal raporlar, en büyük geçmişe ve en yaygın kullanıma sahip olan kurumsal rapor türüdür. Finansal raporlar ile kastedilen işletmelerin finansal raporlama süreci sonunda oluşturdukları finansal tabloların sunumudur. Bu sunum ise günümüzde genel olarak bağımsız denetim raporları ile sağlanmaktadır. Bağımsız denetim raporlarında ayrıntılı olarak gösterilen ve finansal raporlama sürecinin bir çıktısı olan finansal tablolar, ayrıca özet bir şekilde işletmelerin yıllık faaliyet raporlarında da gösterilmektedir. Bir diğer taraftan işletmeler "finansal rapor" ismi ile bir rapor sunmamaktadırlar. Finansal raporun temelini oluşturan finansal tabloların sunumu finansal raporlama süreci sonunda işletme paydaşlarına "bağımsız denetim raporu" ve/veya "yıllık faaliyet raporu" ismi ile sunulmaktadır. Rapor dışında ise finansal tablolar ve bu tablolardaki veriler, işletmelerin internet sitelerinde yer alan yatırımcı sunumları, özet finansal veriler gibi başlıklar altında da sunulmaktadır.

Finansal raporlar aracılı̆̆ıla sunulan bilgiler, yıllar boyunca işletme performansının değerlendirilmesinde kullanılan en önemli kaynak olmuştur. Küresel ekonomik krizler ve işletme skandalları ile birlikte işletmelere dair sadece finansal raporlar üzerinden yapılan değerlendirmelerin yetersiz kaldığı görülmüştür. Dünyanın bir noktasında yaşanan afetlerin dünyanın diğer noktalarındaki üretimi durdurması, azalan doğal kaynakların hammaddeleri tehdit etmesi ve benzeri gelişmeler, finansal raporlarda yer almayan risklerin şirketler için finansal sonuçlara yol açabildiğinin göstergesi olmuştur. $\mathrm{Bu}$ doğrultuda işletmelerin karşı karşıya olduğu çevresel, sosyal, yönetimsel riskler ile belirsizliklerin işletmenin sürekliliğini ve sürdürülebilirliğini doğrudan ya da dolaylı olarak etkilediğini gören işletme paydaşları, işletmelerden finansal olmayan performanslarına ilişkin bilgi talep etmeye başlamışlardır (Aras \& Sarığlu, 2015). Bu da ağırlıklı olarak finansal raporlara dayalı gerçekleşen kurumsal raporlamanın değişimini başlatmıştır.

Bu çalı̧̧mada öncelikle işletmenin paydaşları ile en güçlü iletişim aracı olarak gösterilen kurumsal raporlara ve bu raporların zaman içindeki değişimine ilişkin açıklamalarda bulunulmuştur. Daha sonra ise kurumsal raporlama sürecinin en önemli aracı olarak gösterilen ve en uzun geçmişe sahip olan finansal raporlama ele alınmıştır. Son bölümde ise kurumsal ve finansal raporlamanın günümüzde sahip olduğu konum, teknoloji çerçevesinde yaşadığı değişim, Covid-19 pandemisinin oluşturduğu etki ile ilgili raporlamaların geleceğine ilişkin yapılan öngörüler incelenmiş ve bunların neticesinde muhtelif çıkarımlar yapılmıştır.

\section{Kurumsal Raporlama: Paydaşlar ile En Güçlü İletişim Aracı}

Farklı paydaşların çeşitli bilgi taleplerini karşılayan bir iletişim aracı olan kurumsal raporlama, işletmelerin hesap verebilirliğinin temel aracıdır (Federation of European Accountants (FEE), 2015). Bu aracın etkinliği ise doğru bilginin doğru kişilere doğru zamanda ulaştırılması ile mümkün olmaktadır (Axson, 2010). Bu çerçevede iyi kurumsal raporlamanın objektif, ilgili ve önemli bilgileri içermesi, tam olması/eksik bilgi içermemesi, güvenilir, karşılaştırılabilir ve doğrulanabilir olması gibi temel niteliksel özellikleri taşıması gerekmektedir (The Association of Chartered Certifed Accountants (ACCA), 2018a).

Kurumsal raporların oluşturulması belirli aşamalardan geçmektedir. Kurumsal raporlama süreci, işletme hakkındaki finansal ve finansal olmayan ham verilerin toplanması ile başlamakta daha sonra ise bu verilerin filtrelenmesi, sınıflandırılması, özetlenmesi gibi çeşitli raporlama süreçlerinden geçerek verilerin bilgiye dönüşmesi ve nihai bir çıtı olarak raporların oluşturulması ile sonuçlanmaktadır. Raporlama sürecinde yer alan katılımcılar (hazırlayıcılar, denetçiler, vb.) bu bilgilere değer katmakta ve tüm bilgiler toplanarak işletmenin kurumsal raporu oluşturulmakta ve paydaşlara sunulmaktadır (Pounder, 2009).

Kurumsal raporlamanın iki temel amacı vardır. Bunlar; kurumsal raporlarda sunulan bilgilerin yatırımcılara, yönetimin şirketin kaynakları üzerindeki idaresini değerlendirme görevi görmesi ve tüm paydaşlara işletme hakkında alınacak 
kararlarda yararlı olan verilerin sağlanmasıdır (Elliott \& Elliott, 2017). Bu amaçlarının yerine getirilmesi, işletme ile paydaşlar arasındaki bilgi asimetrisini azaltmaktadır. Özellikle, işletme yöneticileri ile yatırımcılar arasındaki bilgi asimetrisi, olumsuz seçim maliyetlerini ve bunun sonucu olarak da diş sermayenin maliyetini arttırmaktadır. Kurumsal raporlarda sunulan bilgilerin kapsayıcıllğı, bilgi asimetrisini azaltarak bu olumsuzluğu giderme yönündeki ihtiyaca cevap verme çabasındadır (Naranjo, Saavedra, \& Verdi, 2014).

Kurumsal raporlama, sürekli genişleyen bir kullanıcı yelpazesinin taleplerini karşılamak için sürekli olarak değişim yaşamaktadır. Bu nedenle kurumsal raporlama durağan bir yapıda değildir, her zaman gelişen ve sürekli değişen bir ortamda dinamik bir yapıya sahiptir (ICAEW Financial Reporting Faculty, 2018). Bu yapı içerisinde etkili olan kurumsal raporlar, bir dizi temel bilgilendirici unsurları içermelidir. Yapılan araştırmalarda da görülmektedir ki geçmişte kurumsal raporlarda ağırlıklı olarak temel bilgilendirici unsur işletmenin performansını yansıtan finansal veriler iken günümüzde ise muhtelif sebeplere bağlı olarak temel bilgilendirici unsurlar daha çeşitlenmiştir. Her ne kadar işletmelerin kurumsal raporlarında bu şekilde bir görünüm olsa da finansal performans verileri bu raporların en az yarısını kapsamaya devam etmektedir (PwC, 2007).

Kurumsal raporlama, işletmenin finansal performansını göstermenin ötesinde işletmenin performansının daha bütünsel bir resmini sağlamalıdır (The Association of Chartered Certifed Accountants (ACCA), 2018b). Bu çerçevede günümüzde kurumsal raporlama, tüm parçaları masaya yayılmış ve net bir resim oluşturmak için bir araya getirilmeyi bekleyen bir yapboz gibidir. Bu yapbozdaki finansal parçalar, standartlar ve temel ilkeler çerçevesinde bir zeminde yer alırken finansal olmayan parçalar ise tam anlamıyla belirli bir zeminde yer almamaktadır. Ayrıca finansal ve finansal olmayan parçaların uyumu konusunda da karışıklıklar yaşanmaktadır. İşletmelerin bu yapbozda net bir resminin ortaya çıkabilmesi adına tüm parçaların belirli standartlarda, net bir şekilde ve uyum içinde bir araya getirilmesi gerekmektedir. Buna dair muhtelif ilgili ve ilişkili kurum ve kuruluşların çalışmaları devam etmektedir (Wilcox \& Sodali, 2019).

Finansal bilgi kullanıcılarının günümüzdeki önemli taleplerinden biri, gelecekteki hissedar değerinin tahmin edilmesidir (Dyckman \& Zeff, 2000). Bunun sağlanması için ise finansal raporlarda sunulan finansal bilgiler ile birlikte değer yaratıcı finansal olmayan bilgilerin bilinmesi gerekmektedir. Paydaşların finansal olmayan bilgilere ilişkin artan talebi, işletmelerin birden çok departman ve sistemden daha fazla veri toplamasına, bu verilerin raporlama süreçlerine dahil edilmesine (sınıflandırma, filtreleme, özetleme, vb.), daha fazla veri mutabakatı yapılmasına (inceleme, düzeltme, onay, vb.), rapor konsolidasyonlarına neden olmaktadır. Bu ise işletmelere fazladan maliyet yüklemektedir. Artan finansal olmayan bilgi talebinin karşılanması bu tür bilgilerin finansal raporlar yerine farklı kurumsal rapor türleri içinde sunulması ile sağlanmaya çalışılmaktadır (Nielsen \& Roslender, 2015). Her ne kadar finansal olmayan bilgilerin farklı kurumsal rapor türleri içerisinde hazırlanması bir çözüm olarak bulunsa da bunların hazırlanması ve sunulması işletmelere ek maliyetler getirmektedir.

Kurumsal raporlama, özellikle son yirmi yılda değişen ihtiyaç ve taleplere bağlı olarak karmaşık bir hal almıştır. Bu süreç öncesinde işletmenin tüm paydaşları için yeterli görülen finansal raporlar ve yıllık faaliyet raporları, farklı bilgi talepleri, artan sosyal sorumluluk ve çevre bilinci, teknolojik gelişmeler gibi nedenlerden dolayı yetersiz olarak görülmeye başlanmıştır (The Association of Chartered Certifed Accountants (ACCA), 2016). Söz konusu durum ve ileriye dönük bilginin artan önemi ile oluşan muhtelif bilgi talepleri, Şekil l'de görüldüğü gibi farklı kurumsal rapor türlerinin oluşumuna yol açmıştır (Deloitte, 2019b). Şekilde yer alan görünümde zaman içinde farklı kurumsal raporlamaların ortaya çıkmasında, "finansal raporlar, bir işletmenin ne yaptığını ve yapacağını gerçekten tam olarak yansitıyor mu?" sorusuna tam olarak evet cevabının verilememesi etkili olmuştur (The Association of Chartered Certifed Accountants (ACCA), 2012) 


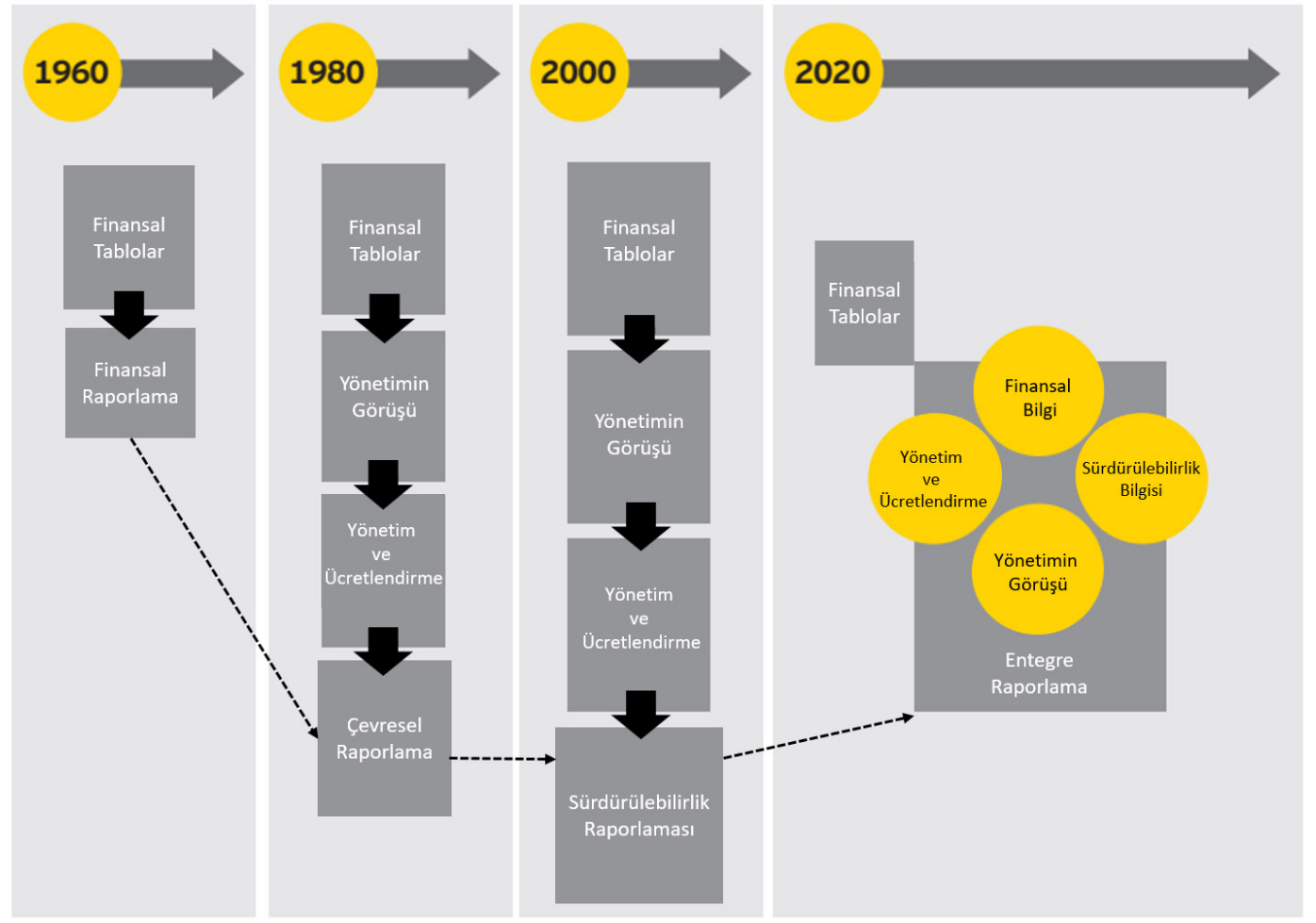

Şekil 1: Kurumsal Raporlamanın Gelişimi

Kaynak: IIRC. (2011). Towards Integrated Reporting: Communicating Value in the 21st Century ve EY. (2014). Integrated Reporting - Elevating Value.

Şekil l'de görüldüğ ü üzere kurumsal raporlar 1960'larda yalnızca finansal tabloları içeren finansal raporlardan oluşmaktaydı. 1980 'lerde finansal tablolara ek bilgiler ile birlikte çevresel raporlar, daha sonra 2000'li yıllarda ise sürdürülebilirlik raporları kurumsal raporlamaya dahil oldu. Günümüzde ise finansal tablolardaki bilgiler yanında yönetim ve ücretlendirme, yönetimin görüşü ve sürdürülebilirlik bilgilerini içeren entegre raporlar iş dünyasında önem kazanmıştır. Raporlamanın yeni normali şeklinde nitelendirilen entegre raporlama, kurumsal raporlamanın geldiği son nokta olarak şeffaflığı ve şirkete ilişkin bilgi paylaşımını artırmakta ve bu sayede bütün paydaşlara fayda sağlamaktadır. Entegre raporların, uluslararası geçerliliği olan düzenlemeler ile birlikte gelecek yıllarda kurumsal raporların öncelikli formu haline geleceği de öngörülmektedir (Aras, 2018; Gökten \& Marşap, 2017).

\section{Bir Kurumsal Raporlama Aracı Olarak Finansal Raporlama}

İşletmeler, belirli bir dönemde gerçekleştirdiği faaliyetler ile ilgili elde ettiği finansal sonuçları finansal raporlar aracilığıyla ilgililere sunmaktadırlar. Finansal raporlar, başta yöneticiler olmak üzere tüm paydaşlara işletme kaynaklarının dönemler boyunca nasıl yönetildiği hakkında bilgi aktaran önemli bir bilgi ve iletişim aracıdır. Finansal raporlama ise içeriği finansal olan veya para ile ölçülebilen bilgilerin raporlanması sürecidir. Bu süreçte işletmenin belirli bir dönemine ilişkin ekonomik durumunu ve performansını gösteren finansal döküman (finansal tablolar ve dipnotları) oluşturulmaktadır (Aerts \& Walton, 2013; Palea, 2013; Pekdemir, 2005).

Finansal raporlamanın amacı, mali tablolar ve dipnotlar aracılığıyla paydaşlara periyodik olarak işletmenin finansal durumu ve performansı hakkında eksiksiz, anlaşılabilir, karşılaştırılabilir, tarafsız ve güvenilir bilgi sunmaktır (Alexander, Britton, Jorissen, Hoogendoorn, \& Mourik, 2014; Uyar, 2015). Hem IASB hem de FASB'a göre ise finansal raporlamanın temel amac1, mevcut ve potansiyel yatırımcılara, borç verenlere, alacaklılara ve diğer taraflara işletmeye kaynak sağlama konusunda karar vermede gerekli bilgileri sağlamaktır (KGK, 2020; Palea, 2013). Bununla birlikte finansal raporlama, finansal tablo analizi ve değerleme süreci ile yatırımcıların ve analistlerin bir firmanın karlılığını ve riskini derinlemesine anlamasına, firmaya değer katacak yatırım kararlarının verilmesine yardımcı olmayı amaçlamaktadır (Wahlen, Baginski, \& Bradshaw, 2015). 
Bilançolar, gelir ve nakit akış tabloları şeklindeki finansal raporlama, geleneksel olarak bir şirket ile mevcut ve potansiyel yatırımcıları arasında yatırımcıların bilinçli yatırım kararları vermelerine olanak tanıyan en önemli iletişim aracıdır (Ditlevsen, Nielsen, \& Thomsen, 2013). Ancak finansal raporlama sadece yatırımcıların karar vermesi için değil, işletme ile ilgili tüm paydaşların bilgi ihtiyaçlarını karşılamak için de önemlidir (Baker \& Wallage, 2000). Bu nedenle finansal raporlama, finansal ekosistemde önemli bir konuma sahiptir. Bu önem çerçevesinde finansal raporlamaya geniş bir ekonomik perspektiften bakıldığında temel amaç, piyasalarda sermayenin etkin dağılımını teşvik etmektir (Deloitte, 2019b; Young, Cohen, \& Bens, 2019).

Finansal raporlamanın sözü edilen amaçlarını gerçekleştirmesi, belirli bir süreçten geçerek nihai olarak finansal raporun ortaya çıkarılması ile sağlanabilmektedir. Finansal raporlama süreci ise işletmelerin niteliğine göre ulusal ya da uluslararası düzenlemeler doğrultusunda gerçekleşmektedir. Bu düzenlemeler içerisinde ise dünya genelinde en yaygın kullanıma sahip olan Uluslararası Muhasebe Standartları Kurulu (IASB) tarafından çıkartılan Uluslararası Finansal Raporlama Standartları (IFRS) setidir.

Finansal raporlama standartları, işletme performansının temel göstergeleri olan finansal tabloları hazırlamak için gerekli ilkeleri, esasları, teamülleri, kuralları ve uygulamaları içeren normlardan oluşmaktadır (Stolowy, Lebas, \& Ding, 2013). Standartlar, kullanıcılara anlaşılabilirlik, karşılaştırılabilirlik ve şeffaflık adına güvence sunmaktadır. Bu güvenceyi sağlayan en önemli unsur standartların getirdiği ilkeler çerçevesinde oluşturulan ve işletmenin performansı ile ilgili detaylı bir görünüm sunan finansal tablolar setidir (White, Sondhi, \& Fried, 2003). Standartlarda yer alan ilkeler, finansal tablolarda yer alan ölçüm ve sunumları daha az öznel hale getirmekte, sonuçta da karşılaştırılabilirlik artmaktadır (Elliott \& Elliott, 2017). Diğer taraftan işletmeler ve diğer finansal rapor kullanıcıları, herhangi bir ülkede standartların uygulanması sonucu yayımlanan finansal tabloları anlayabilmekte, karşılaştırabilmekte ve bu raporlara güvenebilmektedir (Stolowy et al., 2013).

Finansal raporlama ortamı ulusal ya da uluslararası birtakım ilkeler ve/veya standartlar düzenlenmemiş olsaydı, finansal bilgi sağlamanın işletmeye sağladığı faydalar, bu bilgiyi sağlamanın maliyetlerini aştı̆̆ı sürece açıklama gönüllü olarak gerçekleşecekti. Ancak çeşitli düzenleyici kurumlar, işletmelerin belirli asgari finansal açıklama düzeylerini karşılamasını sağlamak adına finansal raporlama gereksinimlerini belirlemektedirler (Revsine, Collins, Johnson, Mittelstaedt, \& Soffer, 2015). İşletmeler ise düzenlemelerin getirdiği zorunluluktan dolayı paydaşlarına finansal raporları periyodik olarak sunmaktadırlar. Ancak işletmeler bu zorunluluk yanında herhangi bir yasal zorunluluğu bulunmayan kurumsal rapor türlerini de paydaşları ile iletişimlerini güçlü tutmak ve şeffaflık sağlayabilmek adına gönüllü olarak yapmaktadırlar.

Finansal raporlama, kurumsal raporlamada önemli bir yere sahipken finansal tablolar da finansal raporlamanın önemli bir unsurunu temsil etmektedir. Finansal tablolar, tarih boyunca sürekli gelişim göstermiş ve zaman içinde ortaya çıkan çeşitli bilgi taleplerine karşılık vererek finansal raporlamanın amaçlarına ulaşmasına yardımcı olmuştur. Ancak son yıllarda değişen koşullar ve yaşanan muhtelif gelişmeler doğrultusunda finansal raporların ve dolayısıyla finansal tabloların talep edilen bilgi ihtiyacını karşılama düzeyi tartışı1ır hale gelmiştir (Beattie, 2000). Şekil 2'de görülen geçmişten günümüze doğru, karar vericilerin (paydaşların) kullandığı bilgilere bakıldığında geleceğe dair şu soruyu sormak gerekmektedir: “Gelecekte finansal tablolar, karar vericilerin ve kurumsal raporlamanın önemli bir parçası olacak mıdır?” Bunu belirleyecek unsur ise finansal tabloların öngörü değerini arttırmasına ve dolayısıyla kullanıcılara değer katacak bilgiler sunmasına bağlı olacaktır. Bunun için gelecek yıllarda finansal raporlamada teknoloji ağırlıklı değişikliklere gidilmesi öngörülmektedir. Şekilde görüldüğü gibi kullanıcıların, karar verirken yıllar içerisinde finansal tablolar haricinde sunulan yapılandırılmamış bilgilere başvurma eğilimi artış göstermiştir. Bunun nedenleri olarak ise finansal tablolarda kilit bilgi eksikliğinin olması ile hacimli ve karmaşı finansal raporlamanın oluşmasıdır ki bu, finansal raporlamanın gelecekte çözmesi gereken önemli konulardan biri olarak gözükmektedir (Federation of European Accountants (FEE), 2015). 


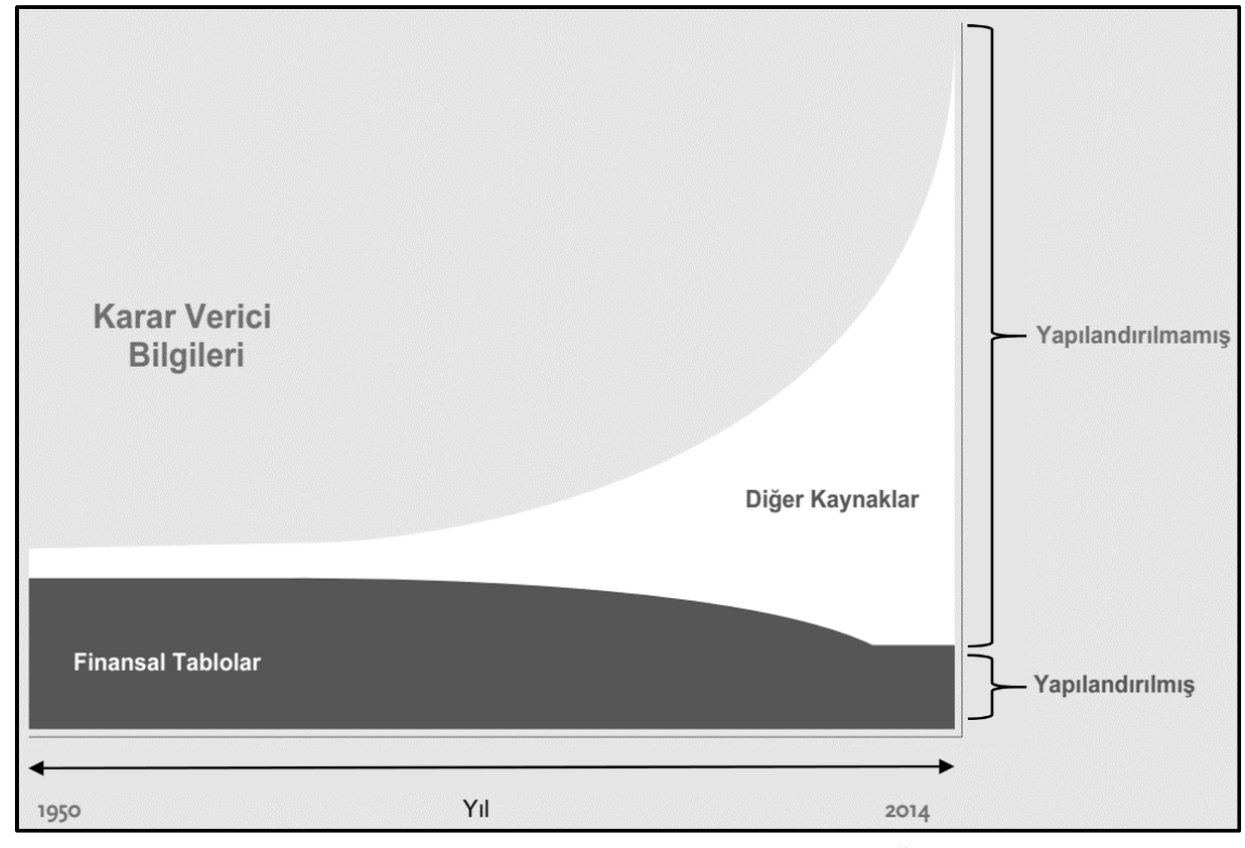

Şekil 2: Finansal Tabloların Görece Azalan Önemi

Kaynak: Federation of European Accountants (FEE). (2015).

Finansal raporlamanın eleştirilen yönlerinden biri de maddi olmayan varlıklar konusunda sınırlamalara sahip olmasıdır. Maddi olmayan varlıkların muhasebeleştirilmesi ve raporlanması, çeşitli nedenlerle eleştirilere konu olmuştur ve son otuz yıldır en tartışmalı konular arasında yer almaktadır (Uzma, 2011). Başlangıçta, yalnızca dışarıdan edinilmiş olmaları durumunda bu varlıkların bilançoda sunulmasına izin verilmekte iken UFRS'ler ile birlikte bu varlıkların değerlemesinde ve muhasebeleştirilmesinde mevcut olan bazı sınırlamalar ortadan kalkmıştır. Ancak halihazırda tartışmalı bir konu olsa da entelektüel sermaye benzeri maddi olmayan varlıkların finansal tablolar setinde gösterilmesi hususunda sınırlamalar mevcuttur (Krstić \& Đorđević, 2010). Değer yaratıcı bu tür varlıkların finansal raporlarda yer almaması paydaşları farklı kurumsal rapor türlerine yöneltmektedir.

Finansal raporlara getirilen eleştirilerden biri de bu raporlarda yer alan bilgilerin artan hacimlerinin paydaşlar için karmaşık bir hal almasıdır. Raporların bu kadar uzun olmasının nedenlerinden biri, önemsiz veya yinelenen bilgilerin dağınık bir biçimde raporlarda sunulmasıdır (CIMA Global, 2009). Bu durum hem ilgili bilgileri hazırlayanların paydaş taleplerini kavrayamamasından hem de yasal düzenlemelerin bu tür bilgileri raporlara eklemeye zorlamasından kaynaklanmaktadır (FSN \& Workday, 2017; The Association of Chartered Certifed Accountants (ACCA), 2012). Söz konusu durum ile paydaşların daha net ve işletme performansını daha iyi açıklayan bilgi talebi ise farklı kurumsal rapor türleri yanında alternatif iletişim kanallarının ortaya çıkmasına neden olmuştur. Bunlardan biri kurumsal raporlar yanında paydaşlara sunulan alternatif performans ölçütleridir. Bu ölçütler, işletmelere esnek tanıyarak performanslarına dair paydaşların talep ettiği bilgileri sunmalarında önemli bir araç olarak artan bir oranda kullanılmaktadır. Avrupa Menkul Kıymetler ve Piyasalar Otoritesi (ESMA) ile diğer uluslararası yetkili kurumlar, yayımladıkları raporlarda gelecekte üzerinde çalışacakları öncelikli konuların finansal olmayan bilgilerin raporlanması, elektronik raporlama ile alternatif performans ölçütleri olduğunu sıklıkla dile getirmektedirler (Grant Thornton, 2018).

\section{Kurumsal ve Finansal Raporlamanın Geleceği Üzerine Değerlendirmeler}

Çalışmanın bu bölümünde üç alt başlık altında değerlendirmelerde bulunulacaktır. Konuya dair yapılan muhtelif araştırmaların sonuçları kapsamında ilk olarak kurumsal raporlamanın, daha sonra ise finansal raporlamanın geleceğine dair öngörülerin neler olduğu tartışılacaktır. Son olarak da tüm dünyada büyük bir etki yaratan ve belirsizlik oluşturan Covid-19 pandemisinin özellikle finansal raporlama üzerinde ne gibi etkileri olacağına dair çeşitli yorumlamalar yapilacaktır. 


\subsection{Kurumsal Raporlamanın Geleceğine Dair Değerlendirmeler}

Tescil Edilmiş Ruhsatlı Muhasebeciler Birliği’nin (ACCA) 2013’te ifade ettiği gibi “Kurumsal raporlamanın geleceği önemli tartışma konularından biridir.” (Deloitte, 2016). Diğer taraftan da kurumsal raporlama, son yıllarda açıklık ve şeffaflık taleplerini karşılamak için önemli bir baskı altındadır. Şeffaf finansal ve finansal olmayan raporlama sağlamak, paydaşların taleplerini karşılamaktan kuruluşun değer yaratma öyküsünü anlatmaya kadar pek çok düzeyde kurumsal raporlama için kritik öneme sahiptir (EY, 2019). Bu önem sebebi ile de kurumsal raporlamanın geleceği ilgili tüm platformlarda tartışılagelmektedir.

Kurumsal raporlama dünyası, paydaşların artan bilgilendirme talebi ile genişlemektedir. Bu durum, kurumsal raporlamadan olan beklentileri ve raporlamanın kapsamını, muhtelif paydaşlar için ise kurumsal raporların güven ve etkinliği konusundaki endişeleri artırmaktadır. Bu da kurumsal raporlamanın etkinliği için önemli zorluklar ortaya çıkarmaktadır. Bunlardan bazıları; yüksek karmaşıklık (İş birimi sayısı, faaliyette bulunulan ülkeler, vb.), raporlama için kullanılan sistem (ERP, Excel, vb.) ve uygulanılan raporlama çerçevelerinin (GKGMI, UFRS, vb.) sayısıdır (EY - Financial Accounting Advisory Services, 2015).

Tüm kurumsal ve finansal rapor kullanıcıları, birçok açıdan kurumsal raporlamanın gelecekteki yönü hakkında bir fikre sahip olsa da önemli öngörüler ve ilerlemeler sağlanmadan önce tüm rapor kullanıcıların ele alması gereken birtakım soruların tartışılması gerekmektedir. Bu sorular özetle aşağıdaki gibidir (ICAEW Financial Reporting Faculty, 2018):

- Kurumsal ve finansal raporlamanın amaçları nelerdir?

- İşletmeler farklı paydaş gruplarının taleplerini ne derece ve ne ölçüde karşılamalı?

- Tek mi, birden fazla mı raporlama yapılmalı?

- Bilgi talebi ve teknolojik gelişim arttıkça kurumsal raporlamada tutarlılık ve güvenilirlik nasıl sağlanacak?

- Maddi olmayan varlıklar ve entelektüel sermaye hakkında kurumsal raporlarda düzenleme yapılmalı mı?

- Büyük veri ve teknoloji, raporlar aracılığı ile kurumsal iletişimin kalitesini gerçekçi bir şekilde arttırabilir mi?

- İşletmeler teknolojik gelişmeye adapte olsa da rapor kullanıcılarının adaptasyonu konusunda neler yapılabilir?

- Tüm bu gelişmelere bağlı olarak raporların güvencesini sağlayan ve sürecin önemli bir unsuru olan denetim ve denetçilerin rolleri, sorumlulukları neler olmalıdır, bunlar nasıl ve kim tarafından belirlenmelidir?

Kurumsal raporlamanın geleceği konusunda yapılan çalışmalardan biri, Finansal Raporlama Konseyi'nin (FRC), kurumsal raporlama konusunda değişiklik önerileri getiren "Kurumsal Raporlamanın Geleceği” isimli projesidir. Projeyi yürütecek danışma grubu; işletmeler, yatırımcılar, sivil toplum örgütleri, akademisyenler, denetçiler, denetim komitesi başkanları, avukatlar ve diğer çeşitli temsilcilerden oluşmaktadır (FRC, 2018a). Grup, aşağıda yer alan hususlar hakkında tartışma ortamı sağlayarak kurumsal raporlamanın geleceği ile ilgili olarak projeksiyon ortaya koymayı hedeflemektedir (FRC, 2018b):

- Mevcut finansal ve finansal olmayan raporlama uygulamalarını gözden geçirilerek, paydaşların neye ihtiyaç duyduğunun güncellenmesi,

- Paydaşların bilgi taleplerini karşılayan farklı kurumsal rapor türlerinin işletmelere maliyetleri ve getirdiği fayda arasındaki dengenin sağlanması,

- Raporlar için denetim ve güvence modellerinin yeniden tasarlanması.

Diğer bir çalışma olan Avrupa Komisyonunun 30 Kasım 2018'de düzenlediği "Dijital ve Sürdürülebilir bir Ekonomide Kurumsal Raporlamanın Geleceği” isimli üst düzey konferansta ise kurumsal raporlama ile ilgili şu maddeler tartışılmıştır (European Commission, 2018): 
- Kurumsal raporlama gelecekte oluşacak bilgi talepleri için uygun mu?

- Kurumsal raporlamada dijital devrimi benimseme zamanı gelmedi mi?

- Kurumsal raporlamanın sürdürülebilirlik konusundaki konumu nedir?

- Kurumsal raporlamanın yasal çerçevesinde ne gibi değişiklikler yapılmalı?

- Ulusal ya da uluslararası farklı kurumsal raporlama düzenlemelerinin getirdiği karmaşık yapı ortak bir çerçevede nasıl basitleştirilebilir?

- Etkisi giderek artan maddi olmayan duran varlıklar hakkında ne gibi düzenlemeler yapılmalıdır?

Muhtelif platformlarda bahsedildiği üzere işletmelerin maddi olmayan duran varlıklarının (marka değerleri, beşerî sermaye, vb.) kurumsal ve finansal raporlara nasıl yansıtılacağı önemli bir sorun teşkil etmektedir. Bir başka ifade ile işletmelerin kapsamlı bir hikâyesini anlatmak adına finansal olmayan bilgilerin kurumsal ya da finansal raporlarda ne şekilde sunulacağ gelecekte tartışılmaya devam edecek olan bir konudur (Skroupa, 2018). Tartışma konusu olan maddi olmayan duran varlıklar, her ne kadar doğrudan finansal olarak ifade edilebilen bir yapıda olmasa da bir işletmenin gelişimini, performansını veya konumunu anlamak için gereklidir. Ayrıca, giderek gelişen bir dijital dünyada, içsel olarak üretilen maddi olmayan duran varlıkların muhasebeleştirilmesi, bu değerlerin genellikle işletmenin piyasa değerinin dörtte üçünü veya daha fazlasını oluşturduğu için yeniden değerlendirilmelidir (Schmidt, 2018). Bu varlıkların kurumsal raporlarda gerçekçi bir şekilde gösterilmesi, yatırımcılar başta olmak üzere tüm paydaşlar için faydalı ve gereklidir (OECD, 2012).

Kurumsal raporlamanın geleceğine yön verecek ilişkilerden en önemlisi raporlama ile teknoloji arasındadır. Teknolojik gelişmelerin doğrudan ya da dolaylı olarak göstereceği etki, kurumsal raporların hazırlanma biçimini ve paydaşlara sunulma şeklini önemli ölçüde değiştirecektir (Federation of European Accountants (FEE), 2015).

İşletmeler, günümüzde raporlarını kendi internet sitelerinde yayımlamakta, böylece paydaşlar istedikleri anda istedikleri raporlara ulaşabilmektedirler. Ancak son yıllarda geliştirme ve standardizasyon sürecinde bulunan “Genişletilebilir İşletme Raporlama Dili” (eXtensible Business Reporting Language-XBRL) ile şirket ve paydaşları arasındaki ilişki daha şeffaf hale gelebilecektir. Hem şirket içindeki paydaşlar, istedikleri yerde ve zamanda ihtiyacı olan bilgiye direkt hem de işletme dişındaki paydaşlar, çeşitli raporlar içinde kaybolmadan filtreleme seçenekleri ile talep ettikleri bilgilere ulaşabileceklerdir. Böylece günümüzün kurumsal iletişim hatalarının giderilmesinde XBRL fayda sağlayacaktır. Akıllı raporlar olarak da ifade edilen XBRL'in UFRS Taksonomisi ile birlikte kullanılması sonucunda oluşan elektronik raporlamanın, IASB ve diğer ilgili kurumlar tarafından yasal düzenlemeler yapılarak Avrupa'da 2020 sonrasında etkili olması planlanmaktadır (Deloitte, 2019a; Wells \& Chartered Accountants Australia and New Zealand, 2020; Willis, Tesnière, \& Jones, 2002).

Kurumsal ve finansal raporlamanın geleceğine dair tartışılacak konulardan biri bu raporların sorumluluğunun kimde olacağ1 ve denetimi konusundadır. Geçmişte denetçiler, sık sık yöneticilerin finansal raporlamadaki eksikliklere karşı sorumluluklarının göz ardı edildiğini ifade etmişlerdir. Ancak, gelecekte oluşturulacak elektronik finansal raporlama ile bu sorumlulukların nasıl paylaşılacağı ve denetimin nasıl yapılacağı önemli hususlardan biri olacaktır. Bu durum, oluşturulan raporların güvencesi ve oluşturulacak yasal düzenlemeler bakımından da önem arz edecektir (Hubble \& Harris, 2019).

Kurumsal raporların geleceği ile ilgili dikkat edilmesi gereken noktalardan biri raporların uzunluğu konusundadır. Günümüzde nispeten küçük bir işletme dahi yaklaşık elli sayfa kurumsal raporlama yapmaktadır ki işletmenin hacmi büyüdükçe bu sayfa sayısının arttığı görülmektedir. Bu durum her ne kadar detaylı bilgi sunuyor gibi gözükse de hem işletmeleri hem de işletmeleri analiz eden paydaşları zorlamaktadır. Bu nedenle işletmelerin daha açık ve öz bir dile odaklanmaları, bir başka ifade ile "daha azının daha fazla" (less is more) olduğu bir anlayışı benimsemeleri gerekmektedir (Leutenegger, 2018). Bu ise gelecekte daha yalın, net ve muhtelif paydaşların ihtiyacına uygun bilgilerin yer aldığı kurumsal rapor türlerinin ortaya çıkmasına neden olabilecektir. 
Kurumsal raporların ilerleyen zamanlardaki konumunu ve değişimini belirleyecek diğer hususlar şunlardır: (1) daha kapsamlı kurumsal raporların yayınlanması sonucunda raporlarda verilen bilgilerin birbirlerinden genel olarak kopuk olmasıdır. Bunun temel nedeni ise bilgilerin genellikle işletme içindeki farklı departmanlar tarafından üretilmesidir. Bu konuda standart bir çalışma düzeninin oluşturulması gerekmektedir (EY, 2014). (2) Kurumsal raporların bu çalışmada da bahsedilen taleplere cevap vermesi için raporların hazırlanmasında baz aldığı yasal düzenlemelerin ilke bazlı olması, bir başka ifade ile kural bazlı olmaması gerekmektedir (Deloitte, 2016). (3) Finansal raporlar dışındaki kurumsal raporlar için finansal raporlama standartları gibi uluslararası geçerliliği ile geçmişi olan kavramsal ve düzenleyici bir çerçevenin olmaması, tutarsızlıkların ortaya çıkmasına ve paydaşların ilgili raporları karşılaşıımasının zor olmasına yol açmaktadır (EY, 2014). Bu sebeple de ilgili raporlar için tıpkı finansal raporlarda olduğu gibi uluslararası geçerliliği olan ve dünya genelinde uygulanabilecek ilkelerin ya da standartların oluşturulması gerekmektedir.

\subsection{Finansal Raporlamanın Geleceğine Dair Değerlendirmeler}

Kurumsal raporların geleceğine yönelik olarak değişimin devam edeceği, ancak bununla birlikte hem finansal raporların hem de yıllık faaliyet raporlarının paydaş nezdindeki görünümünün en azından orta vadede önemli olmaya devam edeceği ifade edilmektedir (ICAEW Financial Reporting Faculty, 2018). Ancak bu önem, finansal raporlamanın değişmeden devam etmesinin yeterli olduğu anlamına gelmemektedir.

Finansal raporlar ile sunulan doğru finansal bilgilerin yatırımcıların güvenini kazanmada ve finansal piyasaların refahını sağlamada önemli bir rol oynadığı açıktır. Ancak finansal raporlara dair en büyük eleştiri, bu raporlarda sunulan bilgilerin işletmenin geçmişteki faaliyetlerinin sonuçlarına dair bilgiler sunması, bir başka ifade ile geçmişi raporlamasıdır. Dolayısıyla finansal raporlar, bir işletmenin stratejik kaynaklarının verimli yönetimi yoluyla orta ve uzun vadede değer yaratma yeteneğini yansıtmamaktadır (EY, 2014). Bu nedenle de kurumsal raporların işletmenin uzun vadeli değer oluşturmasını etkileyen tüm finansal-finansal olmayan unsurlara ilişkin bilgileri doğru, eksiksiz, bir sistem dahilinde açıklaması ve finansal olmayan bilgileri finansal bilgiler ile uyumlu hale getirmesi önemlidir (Erasmus Research Institute of Management (ERIM), 2020; Sipahi \& Arsoy, 2010).

Temelleri on beşinci yüzyılın sonlarından gelen ve bugünkü konsolide biçimine yirminci yüzyılın ilk yarısından itibaren kavuşan geleneksel finansal raporlamanın, modern toplumu ve ekonomiyi kavrayamadı̆̆ ifade edilmektedir (Mähönen, 2020). Finansal raporlamanın geleceğini etkileyecek bu durumun işletme paydaşlarının karar verme süreçlerinde ihtiyaç duydukları bilgilerin neler olduğunun ve teknolojik değişimin iyi okunduğu ölçüde değişebileceği belirtilmektedir. Bu ise finansal raporlamanın sahip olduğu sınırlamaların çözüme kavuşturulması ile sağlanacaktır. Maddi olmayan varlıkların değerinin değerlendirilmesinde faydası olacak bilgiler, risk ve belirsizlik hakkında daha spesifik bilgiler, ihtiyatlı olmaktan ziyade tarafsız bilgiler, ne kadar kazanç yönetiminin kabul edilebilir olduğunun belirlenmesi gibi alınacak aksiyonlar finansal raporlamanın sahip olduğu bazı sınırlamaların ortadan kaldırılmasına katkı verebilecektir (Barth, 2018).

Finansal raporlar, nispeten basit belgelerden pek çok paydaş için karmaşık belgelere dönüşmüştür. Bu nedenle de finansal raporlamanın geleceğini tahmin etmek zorlaşmaktadır. Ancak en muhtemel senaryo, finansal raporların işletmeler ilgili finansal ve diğer bilgi türlerini sağlayan elektronik bilgi sistemlerine dönüşmesi olarak gözükmektedir. Her ne kadar finansal raporların mevcut halinden teknolojik unsurlar ile başka bir yöne evrilmesi öngörülse de etkin kurumsal yönetimin temel bir bileşeni olarak finansal raporlamaya her zaman ihtiyaç duyulacaktır (Baker \& Wallage, 2000). Diğer olası senaryo ise uzak bir ihtimal olarak görünse de tek bir küresel raporlama modeli çerçevesinde finansal raporların entegre raporlar içerisine tam anlamıyla yerleştirilmesidir (The Association of Chartered Certifed Accountants (ACCA), 2012).

Bilgi teknolojisi, iletişim ve sermaye piyasalarındaki tüm unsurların yanında işletmelerin stratejilerini ve faaliyetlerini etkilerken işletme finansal raporlarının yapısında fazla bir değişikliğe neden olmamıştır. İşletme performansını yansıtan finansal raporlardaki asıl değişiklik, işletmenin bu raporları oluşturma ve işletme paydaşlarının da bu raporları analiz etmesinde yaşanmıştır. Bir başka ifade ile finansal rapor kullanıcıları, yüz yıl önce, bugünkü benzerleri gibi finansal 
tablolar kullanmakta iken kullanıcıların bu raporları oluşturma ve bu raporlardan hareketle işletme performansını analiz etme araçları değişmiş ve değişmektedir (Lev \& Gu, 2016).

Dijital ya da elektronik raporlama olarak ifade edilen finansal raporlamanın geleceğine dair kullanımlar, paydaşların finansal raporlardan hangi bilgilere ihtiyaç duyduklarını belirlemelerine ve bu verileri karar vermelerini geliştirecek şekilde kendi seçtikleri bir formatta elde etmelerine yardımcı olacaktır. Dolayısıyla işletmeler arasında daha iyi karşılaştırılabilirlik sağlanarak finansal rapor kullanıcıları için daha iyi sonuçlar elde edilecektir (Wells \& Chartered Accountants Australia and New Zealand, 2020).

Son araştırmalara göre optimize edilmiş teknoloji ve süreçler, günümüzün karmaşık finansal raporlaması için başarının itici güçleri olmaya devam edecekler, ancak bunula birlikte ortaya yeni zorluklar da çıkacaktır. Workiva'nın 800'den fazla yatırım, muhasebe ve raporlama uzmanı ile gerçekleştirdiği “2018 Finansal Raporlama Araştırması: Zorluklar ve Eğilimler” başlıklı araştırmasına göre finansal raporlama ile ilgili gelecekte yaşanabilecek olası zorluklar şu maddeler halinde özetlenmektedir (Workiva, 2018):

- Elektronik sayfalarda, belgelerde ve sunumlarda ilgili verileri doğrulamanın, finansal raporlama için zorluk oluşturacağı tahmin edilmektedir.

- Finansal raporlamada yer alan verilerin bütünlüğü sağlamak ve verileri yönetmek, raporlama sürecinde yer alan ekiplerin önündeki engellerden biridir.

- Teknolojide sağlanan ilerleme ile birlikte yaşanan hızlı değişim, finansal raporlama sürecinde de sürekli güncelleme yapılmasını gerektirmektedir.

- Teknolojik gelişmelere bağlı olarak yapılacak değişikliklerin maliyeti, işletmeler için önceden düşünülmesi ve planlama yapılması gereken konulardan biridir.

- Veri toplama, işleme ve incelemeleri ile ilgili uzmanların teknoloji konusunda da eğitim alma ihtiyaçları ve buna yönelik kaynak aktarımı önemlidir.

Finansal raporlama ve standartlarının yararları karşısında taşıdığı birtakım zorluklar, finansal raporların kullanışlılığı ve anlaşılabilirliğindeki bazı olumsuzlar meydana getirebilmektedir. Bu zorluklar ve zorluklar karşısında finansal raporlama ile ilgili gelecekte yapılabilecek iyileştirmeler aşağıdaki gibi ifade edilmektedir (Brockett \& Rezaee, 2012):

- Zorluklar:

- Raporlamadaki ileriye dönük bilgi eksikliği.

- Zor ve sıklıkla değişen finansal raporlama standartları,

- Finansal raporlamada gerçeğe uygun değerin aşırı kullanımı,

- Karmaşıklık sonucu finansal raporların okunabilirliğinin azalması,

- İşletmelerin, sürdürülebilirliğe odaklanmak yerine geçerli yasalara, kurallara, düzenlemelere, standartlara ve k1sa vadeli performansa odaklanması.

- Gelecekte yapılabilecek iyileştirmeler:

- İlgili paydaşlara yönelik özet raporlama yapılması,

- Daha faydalı ve alakalı finansal bilgilerin seçilmesi,

- İşletme içi ve dışı sunulan raporların daha iyi entegre edilmesi, 
- Finansal raporlama sürecindeki katılımcılar ile iletişimi geliştirmek,

- Kolayca erişilebilen elektronik verilerin kullanılması (örneğin, XBRL).

Son madde de görüldüğü üzere dijital finansal raporlama ve XBRL’nin benimsenmesi, hem finansal raporların nasıl hazırlandığı hem de finansal raporların nasıl kullanıldığg açısından finansal raporlamayı önemli ölçüde yeniden şekillendirme potansiyeline sahiptir (Wells \& Chartered Accountants Australia and New Zealand, 2020).

Teknolojinin muhasebe, finansal raporlama ve denetimin geleceğini şekillendirmesinde ele alınacak önemli unsurlardan biri de çoğu uzman tarafından kripto paraların da temelini oluşturun blokzincir (blokchain) teknolojisi olarak kabul edilmektedir (Deloitte, 2018). Finansal Yönetici Araştırma Vakfı, 2018 yılında yayımladı̆̆ı "Liderler İçin Blockchain: Fırsata Karşı Gerçeklik” isimli raporunda blokzincir ve finansal raporlama ilişkisine dair şu iki noktaya vurgu yapmaktadır (Financial Executives Research Foundation (FERF), 2018):

- Blokzincir teknolojisini çeşitli muhasebe ve finansal uygulamalarına dahil etme konusunda sektör paydaşları ile konuşulmakta, finansal raporlama uzmanları ile de bu teknolojinin finansal tablolara dahil edilmesinin yolları araştırılmaktadır.

- "Blokzincirin teorik bir uygulaması finansal raporlamadır ve bunun avantajları ile dezavantajlarını tartışmanın ve ortaya koymanın tam zamanıdır.” (Duke Üniversitesi Fuqua İşletme Okulu Maliye Profesörü Campbell Harvey)

Blokzincir teknolojisinin finansal raporlama açısından bir fırsata dönüştürülmesi gerekliliği birçok kesim tarafından sıklıkla dile getirilmektedir. Ancak bunun olası etkileri konusunda uygulamaya yönelik neler olacağı ile ilgili soru işaretleri söz konusudur. Buna cevaben ise olası uygulamalar olarak aşağıda yer alan hususlar öngörülmektedir (Sakız, Dursun, \& Sak1z, 2019):

- Blokzinciri defterlerinin, e-belgeler aracılı̆̆ 1 ile kodlar, algoritmalar ve akıllı sistem sayesinde ilgili blokzincirindeki bloklara aktarılması ile defterlerin otomatik doldurulması söz konusu olacaktır.

- E-kayıtların kullanılarak işletmenin her paydaşı ya da departmanı için ihtiyaç duyulan raporlar, elektronik şekilde anlık olarak otomatik oluşturulabilecektir.

- Bütün finansal işlemlerin elektronik arşivlerde saklanması mümkün olacaktır. Bu süreçlerin dijital olması, finansal tabloların uygunluk denetiminin de blokzinciri üzerinden yapılabilmesini sağlayacaktır.

- Muhasebenin ve raporlamanın bütün fonksiyonlarının dijitalleşmesi ve akıllı hale gelmesi, meslek mensubuna ihtiyacı ortadan kaldırmayacak ancak iş tanımını ve sahip olmaları beklenen yetkinlikleri değiştirecektir.

Blokzincir ile benzer şekilde muhasebe ve kurumsal raporlama da işletmedeki işlemlerin kalıcı ve güven yaratacak şekilde kayıtlarını oluşturmak için tasarlanmış mekanizmalardır. Bu nedenle, birçok kesimin muhasebe ve raporlama sektöründe bir sonraki aşama olarak blokzinciri göstermesi şaşırtıcı değildir. Bu doğrultuda blokzincirin gelecek yıllarda hem raporlama hazırlayıcılarına hem de kullanıcılarına değer katabilecek birçok özellik sunması beklenmektedir (ToomseSmith, 2018). Uzmanlar tarafından bu teknolojik unsurun raporlama süreçlerine kısa sürede entegre olacağının ifade edilmesi de blokzincir teknolojisinin işletmelerin uzun vadeli planlar oluştururken dikkate alınması gerektiğini açıkça göstermektedir (Financial Executives Research Foundation (FERF), 2017).

Finansal raporlama ile teknoloji ilişkisinde geleceğe dair önemli konulardan biri de en son 2018'in sonlarında Melbourne'de yapılan Yeminli Mali Müşavirler (Certified Practising Accountant-CPA) Kongresinde de ifade edilen bulut bilişim (cloud computing) ve yapay zekâ (artificial intelligence) teknolojisidir. Blokzincir, vb. teknolojik gelişmeler ile birlikte bulut bilişim de özellikle elektronik finansal raporlama konusunda gelecekte önemli bir role sahip olacaktır. Yapay zekâ ise raporlama veya denetim süreci için önemli hale gelecek ve yatırım kararı verilmesi sürecinde yatırımcılar tarafından kullanılacaktır (Kaye, 2018). 
Yukarıda yer alan şekilden hareketle finansal raporlamanın geleceğine dair getirilen önerilerden biri de ekstra finansal raporlama (extra-financial reporting) yapılmasıdır. İşletmelerin, ulusal düzenlemeler, standartlar ve diğer unsurlar çerçevesinde hazırlamak zorunda oldukları raporlar ile birlikte özel olarak belirli bir grubu ilgilendiren ve ortak bilgi talebinde bulunan gruplara yönelik özet şekilde ekstra finansal raporlar sunulması önerilmektedir. Ancak bunun için iyi kurulmuş bir raporlama sistemi, donanımlı süreç ekipleri ve kaynak gereksinimi, bu fikrin uygulamaya geçememesini, tartışılma boyutunda kalmasını sağlamaktadır (Kendall, 2018).

\subsection{Covid-19 Pandemisinin Raporlama Üzerindeki Etkilerine Dair Değerlendirmeler}

Martin Gruell'in “Finansal raporlama, sürdürülebilir ekonomik kalkınma için önemli bir yapı taşı1ır.” ifadesi, Covid-19 gibi dönemlerde gerekli şeffaf bilgi sunumu adına daha önemli hale gelmektedir (Frerejacque, 2020). Piyasa ve yatırımcı güveni için kurumsal ve finansal raporlarda şeffaflık önemlidir. Bu raporlar ile kurulacak iletişimin açık, öz, etkili olması ve gereksiz ayrıntılarda kaybolmaması gerekmektedir (ASIC, 2020). Aksi takdirde özellikle pandeminin oluşturduğu bu gibi belirsizlik nedeniyle, yatırımcılar riskten kaçındıkça ve daha güvenli yatırımları tercih ettikçe finansal piyasalar oynak hale gelecektir. Firmalar için öz sermaye kıtlaşacak, özel yatırımlar azalacak, üretim düştükçe arz etkilenecek, işletme maliyetleri artacak ve kâr düşecektir. Bu da firmaların düşük performansına yol açacaktır. Bu gibi belirsizlik dönemlerinde işletmeler, belirsizliğin işletme performansı üzerindeki etkisini azaltmak adına kurumsal ve finansal raporlamalarında çok dikkatli olmalıdırlar (Ozili, 2020).

Günümüzde her ne kadar rapor kullanıcılarının işletmelerden talep ettikleri bilgi artsa ve farklı kurumsal raporlar ortaya çıksa da işletme performansının analizinde, finansal raporlar hâlâ önemli bir yere sahip bulunmaktadır (Renier \& Blomme, 2018). Bunun nedeni ise iyi bir finansal raporlamanın, kaybedilen güvenin yeniden kazanılmasına yardımcı olmada önemli bir role sahip olmasıdır (KPMG, 2013). Bu tespit, özellikle 2020 yılında etkisi hissedilen ve büyük bir etki ile belirsizlik ortamı oluşturan Covid-19 pandemisinde daha öne çıkmaktadır.

Yatırımcılar başta olmak üzere işletme paydaşları, Covid-19'un işletmede üzerindeki olası etkileri hakkında bilgi talep etmektedirler. Bu talep ise özellikle finansal bilgi ağırlıklıdır (Financial Reporting Council (FRC), 2020). Bu dönemde işletme ile ilgili öğrenilmek istenen ilk finansal bilgiler; işletmenin likiditesi/likit varlığı/nakit mevcudu, ödeme gücü ve potansiyel finansman olanaklarıdır. Görüldüğü gibi işletme paydaşları Covid-19'un sadece işletmenin faaliyetlerinde meydana getirdiği etkiye dair değil, aynı zamanda gelecekteki olası etkilerine dair veriler içeren finansallarına ilişkin de bilgi talebinde bulunmaktadırlar (Grant Thornton, 2020).

Covid-19'un işletmelerin finansal raporlama süreçlerinde oluşturduğu en önemli etkiler, iş ve işletme sürekliliği ile raporlama dönemi sonrası olaylar üzerinde olmakla birlikte bu hususlar ile sınırlı değildir. Covid-19'un finansal raporlar üzerinde oluşturduğu en büyük etkilerden biri işletme gelirleri ile ilgilidir. Bunun nedeni ise hasılatın, işletmenin finansal performans tablosunda en üst sırada yer alması ve yatırımcılar, analistler ile diğer paydaşlar için genellikle kritik bir kalem olmasıdır. Pandemi de sonuç olarak, bu kaleme ait tutarı, tahmini ve zamanlamayı büyük ölçüde etkilemektedir (Warren, 2020).

Finansal raporlamanın doğasında bulunan tahmin süreçleri, pandemi ortamında etkilenecek önemli raporlama hususlarından bir diğeridir. Covid-19 etkisinin hissedildiği dönemlerde finansal tabloların birçok önemli kalemini etkileyecek olan muhasebe tahminleri öncelikle; değer düşüklükleri, gerçeğe uygun değer, net gerçekleşebilir değer, geri kazanılabilir tutar, nakit akışları, vb. üzerinde değerlendirmeye tabi tutulacaktır. Örneğin, piyasalarda Covid-19 gibi benzeri olayların oluşturduğu belirsizlik ortamında, gerçeğe uygun değerin belirlenmesi ya da nakit akışlarının tahmin edilmesi, iskonto oranının belirlenmesi çok daha karmaşık olmaktadır (DeLoach, 2020).

İşletme sürekliliğin değerlendirilmesi başta olmak üzere muhtelif olaylar için gereken muhasebe tahminlerinin yapılması UFRS açısından zorunlu tutulmakla birlikte bu varsayımlar hakkında açıklanması gereken bilgilerin neler olduğu standartlarda kesin ifadelerle yer almamakta ancak genel olarak varsayımların niteliği, beklenen olasılıkların gerçekleşme aralığı, geçmiş varsayımlara göre yapılan değişiklikler gibi açıklamaların yapılması istenmektedir (Grant Thornton, 2020). 
Covid-19 salgınının kapsamlı ve öngörülemez doğası nedeniyle denetçiler de işletmelerin muhasebe tahminlerine ilişkin değerlendirmelerinin gelecekteki raporlama dönemlerinde normalden daha karmaşık olmasını beklemektedirler (Radigan, 2020).

İşletmelerin bu belirsizlik döneminde finansal raporlarında paydaşları ile iletişimi sağlayacağ önemli açıklama araçlardan biri de dipnotlardır. Finansal raporlarda ve tablolarda yer alan dipnotlar, müteakip olaylara, bunların işletmenin faaliyetleri üzerindeki potansiyel etkisine, hatta işletmenin faaliyetleri ve sürekliliğine ilişkin mevcut belirsizliklere ilişkin bilgileri içermektedir. Finansal tablolardaki dipnotların içeriği işletmenin kendi ve içinde bulunduğu sektörün koşullarına bağlıdır ve borçluluk seviyesi, likidite, finansman çekme yeteneği vb. durumlardan etkilenmektedir (ICJCE, 2020). Örneğin, işletmelerin yapacakları varsayımların birden fazla analizde kullanılabilmesinden dolayı bu varsayımlar tutarlılık göstermelidir. Farklı olaylar için farklı varsayımlar kullanıldığında ise bu durumun şeffaf bir şekilde dipnotlarda açılanması gerekmektedir (Deloitte, 2020).

Covid-19 gibi olaylar, özellikle oluşturduğu belirsizlik dolayısıyla uzun vadeli etkiye sahip olmakta ve bütçelemeyi de zorlaştırmaktadır. Bu durum aynı zamanda geleneksel bütçe tahminleri konusundaki düşüncenin de değişime uğramasına ve finansal raporlar ile birlikte alınacak kritik kararlarda değişime neden olabilecektir (Parker, 2020). Pandemi nedeniyle finansal raporlama ile ilgili olarak etkilenecek kalemlerden biri de ertelenmiş vergilerdir. Bu süreçte işletmelerin ertelenmiş vergi yükümlülükleri değer düşüklüğü nedeniyle azalabilmekte iken aynı zamanda ertelenmiş vergi varlıklarının geri kazanılabilirliğinin de yeniden değerlendirilmesi gerekmektedir (ICAN, 2020).

İşletmelerin pandemi sürecinin ekonomiye olan etkisini en bariz hissedildiği bu süreçten başarılı bir şekilde ya da en az hasarla çıkabilmeleri için risk yönetimini de iyi yapmaları gerekmektedir. Bunun için ise bu süreçteki hem işletme içindeki hem de işletme dışındaki riskleri iyi tanımlamaları, riskleri rakamlara çevirmeleri, riskleri önlemeye yönelik tedbirleri almaları, risk yönetimini işletmeye yaymaları, riskleri iyi bir şekilde takip etmeleri ve tüm bunları paydaşlarına iyi bir şekilde açıklamaları gerekmektedir (Demir, 2020).

Covid-19; müşteriler, çalışanlar, vatandaşlar gibi insan deneyimlerini değiştirmiştir. Sonuç olarak tutum ile davranışlar da salgın öncesine göre farklılaşmıştır (Accenture, 2020). Bu durumun göz ardı edilmesi işletmelerin finansal açından kayba uğramasına neden olabilmektedir. (KPMG, 2020b). Pandemi ile işletmelerin karşıllaştıkları risk faktörleri önemli ölçüde değişmekle birlikte mevcut olan risk faktörlerinin düzeyi de artış göstermiştir (Köylüoğlu, 2020). Donald Cressey’nin sahtekarlık üçgeni, sahtekarlık veya yolsuzluk yapan birine katkıda bulunan firsat (örneğin, belirsizliğin yol açtı̆̆ kontrol ve denetim boşlukları), güdü (örneğin, ailenin gelir kaybı nedeniyle mali sıkıntıya girmesi) ve rasyonalizasyon (örneğin, dolandırıcıların davranışlarını haklı çıkarmak için davranışlarını rasyonelleştirmeleri, "Şirkete çok şey verdim, böyle zamanlarda bir şeye ihtiyacım var" gibi) faktörlerini açıklar. Üç faktörden herhangi birindeki artış, sahtekarlık ve yolsuzluk riskinin arttırmaktadır. Covid-19, her üçünde de önemli artışların sağlanmasına ve işletmelerin finansal açıdan sıkıntı yaşamasına yol açabilmektedir. (Mitchell, 2020). Sonuç olarak işletmelerin bu durumu göz önüne almaları ve bundan dolayı finansal raporlarında oluşabilecek etkileri azaltmaları gerekmektedir.

Finansal raporlamalardan hareketle oluşturulan ve işletme performansının son yıllardaki önemli bir göstergesi olan alternatif performans ölçütleri de pandeminin oluşturduğu olumsuz ortamdan etkilenmiş̧ir. Ölçütlerin düzenleyicisi olan Avrupa Menkul Kıymetler ve Piyasalar Otoritesi (ESMA), bu süreçte ölçütlerin oluşturulmasında ve sunulmasında işletmelerin dikkatli olmalarını, kullanılan varsayımların açıkça belirtilmesini, Covid-19'un ölçütler üzerindeki etkisine dair değerlendirmelerin net olarak açıklanmasını, yanlış yönlendirmeye neden olabilecek ölçütlerin kullanılmamasını, ölçütlerin piyasaya şeffaf ve faydalı bilgiler sağlayıp sağlamadığını, karşılaştırılabilirliğini ve güvenilirliğini dikkatlice değerlendirmelerini hatırlatmaktadır (ESMA, 2020).

Pandeminin etkileriyle ilgili işletme açıklamaları genel olarak finansal raporlar vasıtası ile paydaşlara sunulmakla birlikte bu raporlarda yer almayan ancak bu raporlardaki finansal bilgileri destekleyecek açıklamaların işletmelerin yıllık faaliyet raporlarında yer alması muhtemeldir. Dolayısıyla faaliyet raporlarında yer alan açıklamalar Covid-19'un ektilerini 
tanımlayan temel varsayımları, belirsizliklere ilişkin varsayımları, bu belirsizliklere ilişkin analizleri içermelidir. Bu analizlerin finansal tablolarda sunulan varlık ve yükümlülüklere ilişkin defter değerleri ile ilişkilendirilmesi ve bu değerle tutarlı olmas1 gerekmektedir (BDO, 2020; KPMG, 2020a).

Pandeminin oluşturduğu belirsizlikler; işletmeleri, ulus devletleri, uluslararası kurumları tedirgin etmekte ve kamu tarafından işletmeler üzerinde temettü dağıtılmaması konusundaki baskıyı arttırmaktadır. Diğer taraftan üst düzey yönetici ücretleri konusunda da meydana gelen baskı işletmelerin kurumsal yönetim anlayışını bu dönemde ciddi bir şekilde gözden geçirmesine neden olmaktadır. (Duman, 2020). İşletmelerin kurumsal yönetim ilkeleri çerçevesinde hesap verilebilir ve şeffaf raporlamalar yapması temel kural olarak tüm dünyada benimsenmiştir. Covid-19 nedeniyle işletmelerin finansal raporlamalarında yer alması gereken ve bunların dışında yapmaları gerekli görülen diğer açıklamalar konusunda Avrupa Birliği’nde European Securities and Market Authority (ESMA) ve UK Financial Conduct Authoritiy (FCA), Amerika Birleşik Devletleri'nde ise Securities and Exchange Comission (SEC) yönlendirici rol üstlenmekte ve işletmelere esneklik tanımaktadır (Yayla, 2020).

\section{Sonuç}

İşletme yapılarındaki, yatırımcı profilindeki, paydaş taleplerindeki ve teknolojideki değişim, çevresel ve sosyal duyarlılık konusundaki ilerleme ile benzeri etmenler, finansal raporlar ile sunulan bilgilerin işletmenin tüm hikayesini anlatmasında yetersiz kalmasına neden olmuştur. Bu nedenle de işletmelerin değerlendirilmesi sürecinde finansal bilgilerin yanında finansal olmayan bilgilere de ihtiyaç duyulmuştur. İşletmeler oluşan bu ihtiyacı, finansal bilgilere finansal olmayan bilgileri de ekleyerek farklı kurumsal raporlar (faaliyet raporu, kurumsal yönetim raporu, sürdürülebilirlik raporu ve entegre rapor) ile paydaşlarına sunarak karşılamaya çalışmaktadırlar. Özetle, kurumsal raporlamanın finansal raporlama ile başlayan gelişimi, detaylı ve çeşitlilik arz eden rapor türleri ile devam etmektedir. Faaliyet ve kurumsal yönetim raporları ile gelişme kaydeden kurumsal raporlamaya 2000'li yıllarda sürdürülebilirlik raporu, 2010'lu yıllarda ise entegre rapor dahil olmuştur.

Kurumsal raporlamanın kapsamı, her ne kadar yirminci yüzyılın sonlarına doğru oldukça büyük değişim yaşasa ve paydaşlarının değişen bilgi talepleri çerçevesinde finansal raporlar dışında kurumsal raporlar oluşturulsa da finansal raporlamaya olan talep etkisini yitirmemiştir. Bir başka ifade ile finansal raporlar önemini ve karar almadaki temel dayanak unsuru olma niteliğini korumaktadır. Bunda finansal raporların uluslararası düzeyde belirli standartlara göre hazırlanması, ortak bir dilin kullanılması, finansal bilgilerin taşıdığı önem ve finansal raporlarda gelen eleştirilere karşı ortaya çıan ve son yıllarda artan bir kullanıma sahip olan alternatif performans ölçütlerinin ya da diğer kurumsal rapor türlerinin her zaman finansal raporların ürettiği bilgilere ihtiyaç duyacak olması gibi unsurlar etkili olmuştur. Ancak bununla birlikte finansal raporlamanın da kendi içinde özellikle paydaş talepleri ve teknolojik ilerleme karşısında değişim gösterdiği kabul edilmektedir.

Finansal raporlar, yarım asırı aşkın süredir kurumsal raporlamanın temel taşı ve sürükleyici unsuru olmuştur. Ancak başlangıcından bugüne endüstriyel bir temelden teknoloji ve bilginin yönlendirdiği bir konuma geçen ekonomik yapı, sosyal ve paydaş beklentilerinin değişmesi gibi faktörler hem finansal hem de kurumsal raporları değişime zorlamıştır. Finansal olmayan bilgiye artan talep, maddi olmayan varlıklara ait bilgilerin önem kazanması, teknolojik değişimin getirdiği büyük veri, blokzincir, bulut bilişim, yapay zekâ, dijital/elektronik raporlamanın raporlama süreçlerine dahil edilmesi gibi hususların hem kurumsal hem de finansal raporların geleceğine yön vereceği öngörülmektedir. Bu süreçte hem raporlama ile ilgili düzenleyicilere hem raporlama sürecini yürütecek işletmelere hem de rapor kullanıcılarına muhtelif sorumluluklar düşmektedir. Bu sorumlulukların etkin bir şekilde ve tarafların iş birliği içinde yerine getirilmesi kurumsal ve finansal raporların işletme ile paydaşlar arasındaki iletişim doğru bir konuma yerleşmesini sağlayacaktır.

Kurumsal ve finansal raporlamanın geleceğine yönelik değerlendirmelerde ifade edilebilecek bir hususta Covid-19'un oluşturduğu belirsizlik ortamına ilişkindir. Covid-19'un ortaya çıkardığı durum işletmelerin finansal raporları başta olmak üzere diğer iletişim araçları aracılığıyla paydaşlarına yapacağı açıklamaların artmasına neden olmuştur. Covid-19 döneminde, ekonomik etkisinden dolayı yatırımcılar başta olmak üzere işletme paydaşları Covid-19 öncesi döneme göre 
işletmelerden finansal olmayan bilgi taleplerini azaltmışlar ve finansal bilgi taleplerini de arttırmışlardır. Bu durum finansal raporların diğer kurumsal raporlara göre bu olağanüstü dönemde daha önemli bir hale geldiğini göstermektedir. Diğer taraftan yapılan çalışmalara göre işletmelerin bu belirsizlik döneminde yürütecekleri finansal raporlama sürecinde iş sürekliliği, işletmenin sürekliliği, likidite, nakit yönetimi, varsayımlar, tahmin süreçleri, devlet yardımları, dipnot açıklamaları, risk yönetimi, denetim faaliyetleri gibi hususlara daha dikkat etmeleri gerektiği belirtilmektedir. İşletmelerin bu dönemde paydaşları ile kuracakları iletişimin kurumsal ve özellikle finansal raporlamaların geleceğine yön vereceği de ifade edilmektedir.

Hakem Değerlendirmesi: Dış bağımsız.

Çıkar Çatışması: Yazar çıkar çatışması bildirmemiştir.

Finansal Destek: Yazar bu çalışma için finansal destek almadığını beyan etmiştir.

Peer-review: Externally peer-reviewed.

Conflict of Interest: The author have no conflict of interest to declare.

Grant Support: The author declared that this study has received no financial support.

\section{Kaynaklar}

Aerts, W., \& Walton, P. (2013). Global financial accounting and reporting: Principles and analysis. Hampshire: Cengage Learning.

Alexander, D., Britton, A., Jorissen, A., Hoogendoorn, M., \& Mourik, C. van. (2014). International financial reporting and analysis. Hampshire: Cengage Learning.

Aras, G. (2018). Kurumsal raporlamada gelecek: Entegre raporlama. Dünya Gazetesi.

Aras, G., \& Sarığlu, G. U. (2015). Kurumsal raporlamada yeni dönem: entegre raporlama. İstanbul: TÜSİAD Yayınları.

ASIC. (2020, Ağustos 15). COVID-19 implications for financial reporting and audit: Frequently asked questions (FAQs). Retrievedfrom:https://asic. gov.au/regulatory-resources/financial-reporting-and-audit/covid-19-implications-for-financial-reporting-and-audit-frequently-asked-questions-faqs

Axson, D. A. J. (2010). Best practices in planning and performance management. New Jersey: John Wiley \& Sons Inc.

Baker, C. R., \& Wallage, P. (2000). The Future of financial reporting in europe: Its role in corporate governance. The International Journal of Accounting, 35(2), 173-187.

Barth, M. E. (2018). The future of financial reporting: Insights from research. Abacus, 54(1), 66-78. https://doi.org/10.1111/abac.12124

BDO. (2020). Potential effects of the coronavirus outbreak on 31 december 2019 year end financial reporting. International Financial Reporting Bulletin.

Beattie, V. (2000). The future of corporate reporting: A review article. Irish Accounting Review, 7(1), 1-36.

Brockett, A., \& Rezaee, Z. (2012). Corporate Sustainability: Integrating Performance and Reporting. New Jersey: John Wiley \& Sons Inc. CIMA Global. (2009). Corporate Reporting (Technical Matters).

DeLoach, J. (2020). How is COVID-19 affecting your financial statements? Editor's Pich (Forbes).

Deloitte. (2016). Thinking Allowed - The future of corporate reporting.

Deloitte. (2018, Ağustos 16). Blockchain and financial reporting - impact of blockchain in the audit function. Retrieved from: https:// www2.deloitte.com/us/en/pages/audit/articles/blockchain-financial-reporting.html

Deloitte. (2019a). IFRS in Your Pocket. London.

Deloitte. (2019b). Rising to the challenge - Adapting to the future of financial foresight.

Deloitte. (2020). Financial reporting considerations related to COVID-19 and an economic downturn. Financial Reporting Alert $20-2$.

Demir, V. (2020). Şirketlerimiz risklerini nasıl yönetebilir? Kobi Girişim.

Ditlevsen, M. G., Nielsen, A. E., \& Thomsen, C. (2013). Corporate reporting: An integrated approach to legitimacy. Journal of Modern Accounting and Auditing, 9(12), 1637-1643. 
Duman, A. (2020). COVID-19 zamanlarında dünyada kurumsal yönetim. TKYD Makale.

Dyckman, T. R., \& Zeff, S. A. (2000). The future of financial reporting: Removing it from the shadows. Pacific Accounting Review, 11(2), 89-96.

Elliott, B., \& Elliott, J. (2017). Financial accounting and reporting. Harlow: Pearson Education Ltd.

Erasmus Research Institute of Management (ERIM). (2020, Ağustos 20). Shaping the future of financial reporting. Retrieved from: www.erim.eur.nl/research/research-impact/erim-impact-narratives/finance-accounting-fa/shaping-the-future-of-financial-reporting

ESMA. (2020). ESMA issues new q\&a on alternative performance measures in the context of COVID-19. Corporate Disclosure.

European Commission. (2018, Ağustos 12). High-level conference on the future of corporate reporting in a digital \& sustainable economy. Retrieved from: https://ec.europa.eu/info/events/finance-181130-companies-public-reporting_en

EY. (2014). Integrated reporting - Elevating value.

EY. (2019). Does corporate reporting need a culture shock? - Meeting the transparency expectations of investors and other stakeholders.

EY - Financial Accounting Advisory Services. (2015). Are you prepared for corporate reporting's perfect storm?

Federation of European Accountants (FEE). (2015). The future of corporate reporting - Creating the dynamics for change. Brüksel.

Financial Executives Research Foundation (FERF). (2017). Blockchain and the future of financial reporting.

Financial Executives Research Foundation (FERF). (2018). Blockchain for financial leaders: Opportunity vs. reality. New Jersey.

Financial Reporting Council (FRC). (2020). Company guidance update march 2020 (COVID-19). COVID-19 Issues.

FRC. (2018a, Ağustos 13). FRC Announces future of corporate reporting advisory group. Retrieved from: https://www.frc.org.uk/news/ december-2018-(1)/frc-announces-future-of-corporate-reporting-adviso

FRC. (2018b, Ağustos 13). FRC to examine the future of corporate reporting, calls for participation. Retrieved from: https://www.frc. org.uk/news/october-2018/frc-to-examine-the-future-of-corporate-reporting

Frerejacque, P. (2020). Advocating for transparency in corporate financial reporting responses to coronavirus. World Bank Blogs (Governance for Development).

FSN, \& Workday. (2017). The Future of financial reporting.

Gökten, P. O., \& Marşap, B. (2017). Paradigm shift in corporate reporting. In S. Gokten (Ed.), Accounting and Corporate Reporting Today and Tomorrow (ss. 1-14). https://doi.org/10.5772/intechopen.68832

Grant Thornton. (2018). IFRS News- A revised 'conceptual framework for financial reporting'.

Grant Thornton. (2020, April 2). Reporting the impact of COVID-19 on your business. Insights.

Hubble, B., \& Harris, M. (2019, Ağustos 15). The future regulation of financial reporting. Retrieved from: http://www.mondaq.com/ uk/x/776422/Audit/Kingman+Review+The+Future+Regulation+of+Financial+Reporting

ICAEW Financial Reporting Faculty. (2018). What's next for corporate reporting: Time to decide? London.

ICAN. (2020). Key accounting, tax and auditing considerations. COVID-19 Practice Alert.

ICJCE. (2020). Possible impact of the COVID-19 Outbreak over the 2019 financial statements and other considerations related to the auditors' tork. COVID-19 Adjuntos.

Kaye, T. (2018, Ağustos 17). Is financial reporting still relevant? Retrieved from: https://www.intheblack.com/articles/2018/10/18/ is-financial-reporting-still-relevant

Kendall, G. (2018). Making extra-financial reporting- fit for the future. The Reporting Times.

Kamu Gözetimi Kurumu. (2020). Finansal raporlamaya ilişkin kavramsal çerçeve (2018 Sürümü). Ankara.

Köylüoğlu, B. (2020). Pandemi sonrası dönemde kurumsal değişim. Stratejivefinans.Com.

KPMG. (2013). The future of corporate reporting: towards a common vision.

KPMG. (2020a). Covid-19 Finansal raporlama üzerindeki potansiyel etkileri. KPMG Görüşler.

KPMG. (2020b). Tackling fraud opportunities arising from working remotely. Forensic Services. 
Krstić, J., \& Đorđević, M. (2010). Financial reporting on intangible assets: Scope and limitations. Facta Universitatis, Series: Economics and Organization, 7(3), 335-348.

Leutenegger, A. (2018). Transparency and trust are crucial. The Reporting Times.

Lev, B., \& Gu, F. (2016). The end of accounting and the path forward for investors and managers. New Jersey: John Wiley \& Sons Inc. Mähönen, J. (2020). Comprehensive approach to relevant and reliable reporting in europe: A dream impossible? Sustainability, 12 (13), 5277. Mitchell, D. (2020). COVID-19: The perfect fraud and corruption storm. KPMG Assurance \& Risk.

Naranjo, P., Saavedra, D., \& Verdi, R. S. (2014). Financial reporting regulation and financing decisions. Massachusetts Institute of Technology (Unpublished Working Paper), 1-55.

Nielsen, C., \& Roslender, R. (2015). Enhancing financial reporting: The contribution of business models. The British Accounting Review, $47(3), 262-274$.

OECD. (2012). Corporate reporting of intangible assets: A progress report. Paris.

Ozili, P. K. (2020). Accounting and financial reporting during a pandemic. SSRN Electronic Journal. https://oi.org/10.2139/ssrn.3613459 Palea, V. (2013). Financial reporting under IAS/IFRS. Bern: Peter Lang.

Parker, D. (2020, Ağustos 10). Budget forecasting in the COVID-19 era. INTHEBLACK.

Pekdemir, R. (2005). Finansal raporlamada terminoloji birliği. Mali Çözüm Dergisi, (72), 21-29.

Pounder, B. (2009). Convergence guidebook for corporate financial reporting. New Jersey: John Wiley \& Sons Inc.

PwC. (2007). Corporate reporting - a time for reflection: Corporate reporting - a time for reflection.

Radigan, J. (2020, Ağustos 17). How the coronavirus may affect financial reporting and auditing. Journal of Accountancy.

Renier, B., \& Blomme, H. (2018). Smarter corporate reporting with core \& more. The Reporting Times.

Revsine, L., Collins, D. W., Johnson, W. B., Mittelstaedt, H. F., \& Soffer, L. C. (2015). Financial reporting \&analysis. New York: McGraw-Hill Education.

Sakız, B., Dursun, G. D., \& Sakız, S. (2019). Muhasebe ve finans alanında önemli dönüşümlerin habercisi: Blok zinciri teknolojisi. In XX. Türkiye Muhasebe Kongresi Cilt 1: Dijitalleşme Sürecinde Değişen İş Hayatı ve Muhasebe Mesleğinin Yeniden Yapılanması "Yerel/Küresel Meseleler, Küresel/Yerel Çözümler” 686-705. İstanbul: TÜRMOB Yayınlar1.

Schmidt, M. (2018, Ağustos 10). The future of corporate reporting. Retrieved from: http://integratedreporting.org/news/ the-future-of-corporate-reporting

Sipahi, B., \& Arsoy, A. P. (2010). Finansal raporlamada yeni yaklaşımlar. Öneri Dergisi, 9(33), 51-57.

Skroupa, C. P. (2018, Ağustos 8). Improving the future of corporate reporting. Retrieved from: https://www.forbes.com/sites/ christopherskroupa/2018/08/30/improving-the-future-of-corporate-reporting

Stolowy, H., Lebas, M. J., \& Ding, Y. (2013). Financial accounting and reporting: A global perspective. Hampshire: Cengage Learning. The Association of Chartered Certifed Accountants (ACCA). (2012). The future of fnancial reporting 2011: global crisis and accounting at a crossroads.

The Association of Chartered Certifed Accountants (ACCA). (2016). Meeting users' information needs: The use and usefulness of integrated reporting. London.

The Association of Chartered Certifed Accountants (ACCA). (2018a, Ağustos 11). Back to basics: What good corporate reporting looks like. Retrieved from https://www.accaglobal.com/gb/en/member/discover/cpd-articles/corporate-reporting/b2b-crcpd.html

The Association of Chartered Certifed Accountants (ACCA). (2018b). Tenets of good corporate reporting. London.

Toomse-Smith, T. (2018). Is the future of corporate reporting block-shaped? The Reporting Times.

Uyar, A. (2015). Kurumsal raporlamanın gelişimi ve güncel yaklaşımlar. Ankara: Gazi Kitabevi.

Uzma, S. H. (2011). Challenges of reporting intangible assets in financial statements. IUP Journal of Accounting Research \& Audit Practices, 10(4), 28-38. 
Wahlen, J. M., Baginski, S. P., \& Bradshaw, M. T. (2015). Financial reporting, financial statement analysis and valuation: A strategic perspective. Boston: Cengage Learning.

Warren, M. (2020). The impact of coronavirus will spread to financial reporting. HLB Mann Judd Article.

Wells, P., \& Chartered Accountants Australia and New Zealand. (2020). The Future of financial reporting - What size do you want? White, G. I., Sondhi, A. C., \& Fried, D. (2003). The Analysis and use of financial statements. Danvers: John Wiley \& Sons Inc.

Wilcox, J., \& Sodali, M. (2019, Ağustos 11). Corporate Reporting. Harvard Law School Forum. Retrieved from: https://corpgov.law. harvard.edu/2019/05/12/corporate-reporting

Willis, M., Tesnière, B., \& Jones, A. (2002). Corporate communications for the 21st century.

Workiva. (2018). 2018 Financial reporting survey: Challenges and trends.

Yayla, Ü. (2020). COVID-19 halka açık şirketlerin bildirim yükümlülüklerine etkileri. TKYD Makale.

Young, S. D., Cohen, J., \& Bens, D. A. (2019). Corporate financial reporting and analysis. New Jersey: John Wiley \& Sons Inc. 